\title{
Ideas and perspectives: Holocene thermokarst sediments of the Yedoma permafrost region do not increase the northern peatland carbon pool
}

\author{
Gustaf Hugelius $^{1}$, Peter Kuhry ${ }^{1}$, and Charles Tarnocai ${ }^{2}$ \\ ${ }^{1}$ Department of Physical Geography, Stockholm University, 10691 Stockholm, Sweden \\ ${ }^{2}$ Research Branch, Agriculture and Agri-Food Canada, 960 Carling Ave., Ottawa, Ontario K1A0C6, Canada \\ Correspondence to: Gustaf Hugelius (gustaf.hugelius@natgeo.su.se)
}

Received: 23 September 2015 - Published in Biogeosciences Discuss.: 11 November 2015

Revised: 2 March 2016 - Accepted: 23 March 2016 - Published: 6 April 2016

\begin{abstract}
Permafrost deposits in the Beringian Yedoma region store large amounts of organic carbon (OC). Walter Anthony et al. (2014) describe a previously unrecognized pool of $159 \mathrm{Pg} \mathrm{OC}$ accumulated in Holocene thermokarst sediments deposited in Yedoma region alases (thermokarst depressions). They claim that these alas sediments increase the previously recognized circumpolar permafrost peat $\mathrm{OC}$ pool by $50 \%$. It is stated that previous integrated studies of the permafrost OC pool have failed to account for these deposits because the Northern Circumpolar Soil Carbon Database (NCSCD) is biased towards non-alas field sites and that the soil maps used in the NCSCD underestimate coverage of organic permafrost soils. Here we evaluate these statements against a brief literature review, existing data sets on Yedoma region soil OC storage and independent fieldbased and geospatial data sets of peat soil distribution in the Siberian Yedoma region. Our findings are summarized in three main points. Firstly, the sediments described by Walter Anthony et al. (2014) are primarily mineral lake sediments and do not match widely used international scientific definitions of peat or organic soils. They can therefore not be considered an addition to the circumpolar peat carbon pool. We also emphasize that a clear distinction between mineral and organic soil types is important since they show very different vulnerability trajectories under climate change. Secondly, independent field data and geospatial analyses show that the Siberian Yedoma region is dominated by mineral soils, not peatlands. Thus, there is no evidence to suggest any systematic bias in the NCSCD field data or maps. Thirdly, there is spatial overlap between these Holocene thermokarst sedi-
\end{abstract}

ments and previous estimates of permafrost soil and sediment OC stocks. These carbon stocks were already accounted for by previous studies and they do not significantly increase the known circumpolar OC pool. We suggest that these inaccurate statements made in Walter Anthony et al. (2014) mainly resulted from misunderstandings caused by conflicting definitions and terminologies across different geoscientific disciplines. A careful cross-disciplinary review of terminologies would help future studies to appropriately harmonize definitions between different fields.

\section{Introduction}

Soils and sediments of the northern permafrost region have accumulated large stocks of organic carbon (OC) over millennia (Tarnocai et al., 2009). As the global climate warms there is a concern that thawing permafrost will expose soil organic matter (SOM) that was previously protected in permafrost to decomposition, causing a positive permafrostcarbon feedback to climate (Schuur et al., 2008, 2015). Hugelius et al. (2014) provide the most recent integrated estimate of Northern circumpolar permafrost region soil and sediment OC stocks with total stocks estimated at $1307 \mathrm{Pg}$ and a $95 \%$ confidence interval of $1140-1476 \mathrm{Pg}$. Of this roughly $800 \mathrm{Pg}$ is perennially frozen with the remainder stored in active layer or talik deposits. A substantial part of the perennially frozen $\mathrm{OC}$ is stored in the Beringian Yedoma region with estimated permafrost deposit OC stocks of $213 \mathrm{Pg}$ with an uncertainty range of $164-267 \mathrm{Pg}$. Schirrmeister et al. (2013) 
provide an in depth discussion and review on various aspects of these deposits. Schuur et al. (2015), in a recent review of the permafrost carbon feedback, highlight that there is considerable spread in estimates of Yedoma region permafrost OC stocks. In a study describing the Holocene $\mathrm{C}$ dynamics of Siberian thermokarst lakes Walter Anthony et al. (2014) estimate a pool of $456 \pm 45 \mathrm{Pg} \mathrm{C}$ in the Beringian Yedoma region. This estimate includes a previously unrecognized pool of $159 \pm 29 \mathrm{Pg}$ OC accumulated in Holocene aged sediments deposited in drained thermokarst-lake basins (hereafter called alases) of the Yedoma region. Walter Anthony et al. (2014) conclude that these alas sediments increase the previously recognized circumpolar permafrost peat OC pool by $50 \%$. It is further stated that previous integrated studies of the permafrost OC pool (Tarnocai et al., 2009; Hugelius et al., 2013a, b) have failed to account for these deposits because of biases in the Northern Circumpolar Soil Carbon Database (NCSCD). They argue that the field site data of the NCSCD is biased towards non-alas sites and that the soil maps on which the database is based are too generalized to show the distribution of, primarily organic, deposits in alases of the Yedoma region. Note that the term alas is used in a wide sense to describe former thermokarst lake basins. Following initial permafrost degradation and thermokarst, these basins have typically been (partly) terrestrialized (e.g., through lake drainage or evaporation of lake water) and re-aggraded permafrost.

Here we examine these important statements by evaluating the findings and data presented by Walter Anthony et al. (2014) against (1) a brief review of vulnerability to climatic changes and scientific definitions of peat, peatlands, organic soils and thermokarst sediments, (2) independent field data as well as independent geospatial databases showing the extent of organic soils and/or peatlands in the Siberian Yedoma region and (3) by analyzing the spatial overlap between these new estimates and existing data sets of Yedoma region soil and sediment OC storage.

\section{Vulnerability and definitions of organic soils and sediments}

Walter Anthony et al. (2014) claim that $159 \mathrm{Pg}$ of OC accumulated in deep Holocene thermokarst deposits across the Yedoma region increase the previously recognized permafrost peat OC pool by $50 \%$. We argue that the use of imprecise terminology has caused misleading comparisons in relation to previous stock estimates. These Holocene thermokarst deposits do not meet the criteria of peat (or organic soils) used in any regional or circumpolar peat carbon stock study. Therefore they cannot be claimed to increase peat carbon stocks. They simply increase the stock of alas sediments known to be of Holocene age.

We emphasize that the properties of mineral and organic soil material are very different and the distinction is espe- cially important in permafrost regions where studies have consistently shown that organic and mineral soils differ both in their vulnerability to thaw and in the potential post-thaw lability of soil OM. Correct classification of organic and mineral soil material is not a mere issue of semantics or putting a different label on something depending on your scientific background. For example, due to distinct differences in soil thermal properties, organic soils are much less vulnerable to active layer deepening under climate warming than mineral soils (Shur and Jorgenson, 2007; Jorgenson et al., 2010). High-resolution modeling of active layer dynamics from a Russian low-Arctic site showed that organic soil is projected to remain stable until the end of this century while nearsurface permafrost degraded in mineral soils (Hugelius et al., 2011). Organic soils also show different vulnerabilities to thermokarst. Thick surface O-horizons can reduce lateral expansion rates of thermokarst (Jorgenson and Osterkamp, 2005) and modelling studies suggest that thermokarst lake taliks formed into organic soils are shallower than their mineral counterparts (West and Plug, 2008). Sjöberg et al. (2013) suggest that thermokarst lake formation and orientation in peatland terrain may partly be controlled by different processes than for mineral soil thermokarst. They also demonstrated that peat substrate thermokarst lake shorelines display more pronounced and heterogeneous erosion patterns than mineral substrate shorelines, both in shoreline morphology and lake geometry. Harden et al. (2006) also describe multiple feedbacks between the thickness of surface organic soil horizons and the vulnerability of ecosystems to combustion by wildfires, where deep organic layers could often preserve thermal and biological properties of soils through repeated fire cycles.

While organic soils are thus less vulnerable to permafrost thaw and combustion than mineral soils, other studies have demonstrated that SOM in organic soils is typically less decomposed than in mineral soils, and thus assumed to be more vulnerable to microbial decomposition. Through comprehensive analyses of Siberian permafrost sediments Strauss et al. (2015) showed that high OC \% content is associated with less degraded SOM, as indicated by multiple geochemical proxies. In sub-Arctic tundra, SOM in peatlands has been shown to be significantly less degraded than mineral soil SOM (Hugelius et al., 2012; Routh et al., 2014). Incubation studies have also confirmed these findings. In a circumpolar incubation synthesis, the fractional loss of initial soil OC was a factor of 2 to 4 higher from organic soils compared to mineral soils (over 50 incubation years at $5^{\circ} \mathrm{C}$ ) (Schädel et al., 2014). In contrast, Weiss et al. (2015) compared surface soils on intact Yedoma to thermokarst basins and found that mineral subsoil samples with lower \% OC (and more degraded SOM as indicated by elemental and stable isotope ratios of $\mathrm{C}$ and $\mathrm{N}$ ) had significantly higher respiration rates per gram OC in short-term incubations than did organically enriched samples. These latter results highlight the complexity of this topic, which clearly warrants further studies. 
In light of these studies showing clear differences in the properties and potential vulnerabilities of mineral and organic soils it is evident that clear definitions and distinctions are needed to properly assess and predict the response of these vulnerable landscapes under a changing climate. Below we provide a brief review of different definitions and classifications currently used in studies of periglacial terrain.

\section{A brief review of definitions of peat, peatlands, organic soils and sediment facies}

Across different scientific disciplines (and countries) the definition of what is peat varies. A commonly used definition states that peat is sedentarily accumulated material consisting of at least $30 \%$ (dry weight) dead organic material while peatlands are areas (with or without vegetation) with a naturally accumulated peat layer (Joostens and Clark, 2002). Many studies have employed a minimum depth criterion of the surface peat layer to the definition of peatland, most frequently $30 \mathrm{~cm}$ (Kivinen and Pakarinen, 1981; Lappalainen 1996; Joostens and Clark, 2002). The Canadian definition of an organic wetland (or peatland) includes a depth of organic soil material (of $17 \%$ OC or $30 \%$ organic material) of at least $40 \mathrm{~cm}$ (National Wetlands Working Group, 1997).

Soil classification systems define organic soil material (or peat) based on organic carbon content, while the thickness of organic soil material in the upper soil column determines whether a soil is primarily considered to be a mineral soil or an organic soil. The U.S. soil taxonomy (Soil Survey Staff, 2010) and the World Reference Base for Soil Resources (IUSS Working Group WRB, 2007) defines waterlogged soil with more than 12-18\% OC (dry weight; range depending on clay content) as organic soil material while the Canadian System of Soil Classification (Soil Classification Working Group, 1998) defines soil with more than $17 \%$ OC (or $30 \%$ organic material; dry weight) as organic soil material. All these soil classification systems define a soil as an organic soil if there is $40 \mathrm{~cm}$ or more of accumulated organic soil material in the upper soil column (the Canadian system employs $60 \mathrm{~cm}$ for highly fibric moss-peat).

The literature describing sediments of thermokarst basins and lakes includes many different definitions of different facies or deposit types. These definitions are often not based on quantified physical or chemical properties of sediments, but rather reflect descriptive characteristics and the environments in which they formed. In addition to in situ peat, previous studies have described organic rich sedimentary thermokarst facies such as the following: (1) "detrital peat" described as layered organic deposits formed on beaches or in shallow waters (Murton, 1996) or as lee-shore deposits (Hopkins and Kid, 1988); (2) "organic rich silts" (or "lacustrine organic silt") where primarily mineral lake sediments are interspersed with sedentary or allochthonous detrital organic sediments layers (Murton, 1996; Kanevskiy et al., 2014) and (3) "Mud/muddy peat" which differs from detrital peat based on a higher mud content. These deposits may contain blocks of peat or other materials and typically form thick sediment layers in deep water thermokarst lake environments by suspension settling of fine and/or low-density material (Hopkins and Kidd, 1988; Murton, 1996).

The bulk of the Holocene OC described by Walter Anthony et al. (2014) has accumulated in sediment facies these authors descriptively call "Stratified muddy peat". The authors state that this facies corresponds to strata that previous authors have called "Mud/muddy peat". These facies are described as deep-water lake sediments, predominantly of minerogenic origin and with an OC content of only 3-4\% by weight (Walter Anthony et al., 2014; Fig. 2 and extended data Table 2). Their use of terminology is in line with previous studies of thermokarst sedimentary facies. But the classification, origin and properties of these deposits are clearly very different from pedologically defined peat as being a primarily organic material, usually of terrestrial or shallow water origin.

\section{Extent of organic soils in the Siberian Yedoma Region}

Walter Anthony et al. (2014) describe a pool of Holocene OC which was previously unrecognized because earlier studies had not systematically accounted for alas deposits. Here we evaluate these statements and present independent evidence showing that their argumentation is based on flawed assumptions. We find no evidence of systematic biases in the data sets on which earlier studies were based.

The Beringian Yedoma region can be subdivided into areas of intact Yedoma (ca. 30\% by area), areas that have been affected by thermokarst and subsequently re-aggraded permafrost $(56 \%)$ and areas of open water (14\%) which are commonly underlain by taliks (Strauss et al., 2013). The study by Walter Anthony et al. (2014) uses an identical spatial subdivision of this region but with different data and computational methods to estimate the volume and OC stocks of the various sediments and deposit types in the region. This includes a thermokarst-basin Holocene carbon pool $(159 \pm 24 \mathrm{Pg})$ which the authors claim to be a newly recognized OC pool that has not been captured in previous studies. The authors present their reasoning for reaching this conclusion (see Walter Anthony et al., 2014, supplementary material Sect. 3.5); they claim that the NCSCD underestimates the spatial coverage of Histels (permafrost peatland soils) and that the pedon data set of the NCSCD is biased towards non-alas soils. The argumentation is based on an assumption that all Siberian alases are fully covered by peat deposits and that all pedons in alas deposits should therefore be classified as Histels. A bias towards non-alas soils in the NCSCD pedon data set $v 2$ is claimed on the basis that only nine out of 60 pedons in the Siberian Yedoma region are classified as Histels. In fact, geomorphological site descriptions 
in Hugelius et al. (2013a, b) clearly show that an additional 13 mineral soil pedons in the NCSCDv2 data set are sampled in alases or thermokarst deposits in the Siberian Yedoma region.

We further evaluate these claims of systematic underrepresentation of organic soils in the NCSCD maps and pedon databases against independent inventories of geospatial data sets and field data. To provide independent estimates of Siberian Yedoma region peatland coverage four different geospatial data sets were used (Nilsson et al., 2002; Bartalev et al., 2003; Lehner and Döll, 2004; Arino et al., 2012). Thematic classes that corresponded to peatlands were identified and their respective coverage quantified. The independent field validation sites are all located in alases or thermoerosional gullies from across the Siberian Yedoma region and were classified and sampled using a transect-based semirandom approach during field campaigns in August (2010 and 2013). For detailed method descriptions and calculations we refer to the online supplementary materials.

Both the geospatial data sets and field inventory data show a limited extent of organic soils in the Siberian Yedoma region (Fig. 1). The mapped Histel coverage in the Siberian Yedoma region in the NCSCD is 9\% (Supplement Fig. S1). This is comparable to peatland coverage estimated from independent geospatial databases of 3-6\% (Fig. 1). It is notable that the degree of overlap between independent data sets is limited, indicative of difficulties with classifications and class definitions when mapping peatland extent (Fig. S1). A spatial overlay analyses of regional land-cover and wetland characterization maps (Nilsson et al., 2002; Stolbovoi, 2002) suggest that $\sim 3 \%$ of the region is covered by deep peat bogs while $19 \%$ is characterized as swamps with very shallow peat $(0.1-0.5 \mathrm{~m}$, mainly corresponding to mineral wetland soils).

Our independent compilation of field sites located in alases or thermoerosional gullies from across the Siberian Yedoma region reveals that $16 \%$ of sites are peatlands (Fig. 1; 9 out of 49 sites). The surface peat depth of these nine peatland sites was $\geq 1.3 \pm 1.1 \mathrm{~m}$ (mean $\pm \mathrm{std}$ ), with a range of 0.4 to $>3.7 \mathrm{~m}$. Reclassifying the original data from Walter Anthony et al. (2014) following pedological definitions yields a remarkably similar result with $16 \%$ of the studied thermokarst features adhering to the soil science definition of an organic soil (Walter Anthony et al., 2016).

The two main processes of global peatland formation (and expansion) are paludification or terrestrialization. Terrestrialization describes peatlands formed via gradual in-filling of water bodies. Paludification is the process by which peatlands expand into other established terrestrial ecosystems. Paludification is considered the most common form of highlatitude peatland formation (Charman, 2002; Kuhry and Turunen, 2006). The bulk of the Holocene alas deposits described by Walter Anthony et al. (2014) were formed through a terrestrialization process in combination with permafrost dynamics (sometimes causing rapid drainage). The charac-

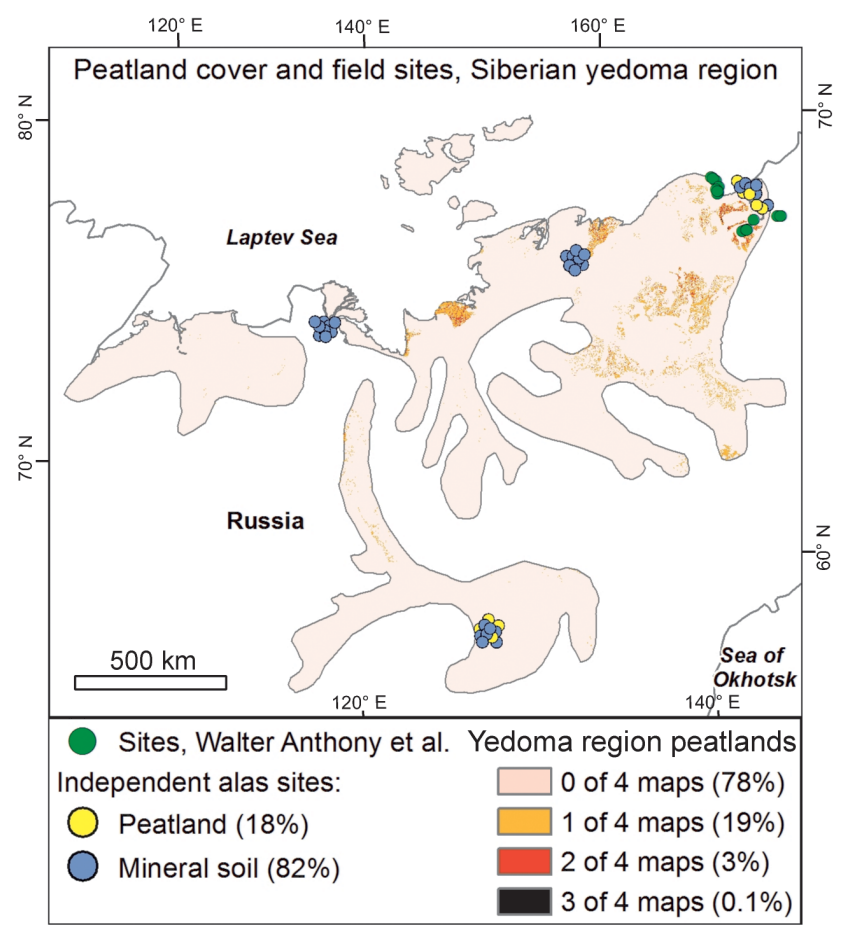

Figure 1. Overview of field sites and estimated coverage of peatlands in the Siberian Yedoma region. Graduated colors within the region show coverage of peatlands in four global and/or regional map products that are independent from the NCSCD (see online supplementary material for detailed methods). The coverage is shown cumulatively so that the colors reflect how many of the four products that map peatlands in any given location. Points show locations of the Holocene alas profiles used by Walter Anthony et al. (2014) as well as independent soil profiles for validation (classified as mineral soils or peatlands). All of the independent validation points are known to be located in alases or thermoerosional gullies. Extent of the Siberian Yedoma region digitized from Grosse et al. (2013).

teristics of peatland sites from across the Yedoma region show that paludification of terrestrial alas ecosystems has also contributed to local peatland formation (e.g., facies F1 in Walter Anthony et al., 2014 see also Palmtag et al., 2015 and Weiss et al., 2015).

All of these combined lines of evidence support an interpretation that peatlands are locally present in alases of the Siberian Yedoma region, but rarely cover large surfaces. We recognize that the maps and pedon data set of the NCSCD are highly generalized, but find no support to the claim that they are systematically biased to non-alas soils. We conclude that the Siberian Yedoma region alases are dominated by mineral soils, often formed on parent material of reworked yedoma or lacustrine sediments. This interpretation is also supported by previous scientific studies from this region (e.g., Czudek and Demek, 1970; Veremeeva and Gubin, 2009; Wetterich et al., 2009; Schirrmeister et al., 2011; Morgenstern et al., 2013; Siewert et al., 2015). 
(a) Alas soil types and thermokarst sediments upscaled separately, no age differentiation

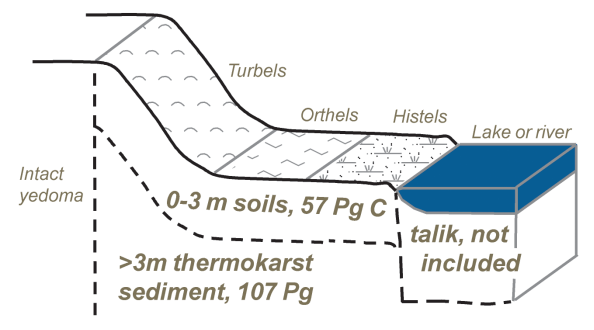

(b) Alas sediments upscaled by genesis and age, assumes uniform surface

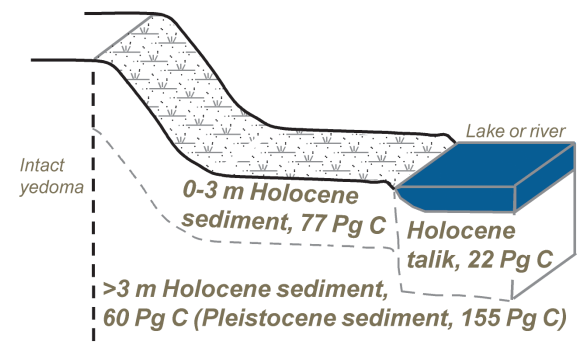

Figure 2. Conceptual diagram illustrating how organic soil/sediment $\mathrm{C}$ in Yedoma region alases is described and estimated by (a) Hugelius et al. (2014) and (b) by Walter Anthony et al. (2014). The graph depicts a Yedoma region alas, including its slopes and any thermoerosional gullies, with $14 \%$ water coverage. In (a) all numbers are derived from Hugelius et al. (2014). The near surface, 0-3 m, soil carbon stocks $(57 \mathrm{PgC})$ were extracted from the NCSCDv2; thermokarst sediment carbon storage below $3 \mathrm{~m}$ depth (107 Pg C) was calculated based on data from Strauss et al. (2013) and subaqueous sediments, which are typically non-permafrost, were not included. Note that in (a) the soil surface is subdivided to represent the areal coverage of different soil classes used in upscaling: Turbels $69 \%$, Orthels $19 \%$ and Histels $13 \%$. In (b) all numbers are derived from Walter Anthony et al. (2014) where carbon stocks are upscaled based on sedimentary facies descriptions which account for the age and genesis of sediment. Walter Anthony et al. (2014) do not actually separate near surface and subaqueous Holocene sediments in upscaling but in (b) these different compartments are shown to enable comparisons. The Pleistocene sediment $\mathrm{C}$ pool of $155 \mathrm{Pg} \mathrm{C}$ in (b) can be subdivided into $23 \mathrm{Pg} \mathrm{C}$ stored in subaqueous sediments and $132 \mathrm{Pg} \mathrm{C}$ stored in terrestrial sediments within $10 \mathrm{~m}$ of the soil surface. See the online supplementary methods for details of calculations.

\section{Overlap between soil C estimates in Yedoma region alases}

Spatial overlap between different studies of soil carbon stocks may mislead data users and cause significant errors in estimates. Walter Anthony et al. (2014) claim that the pool of $159 \mathrm{Pg}$ Holocene OC in Yedoma region alases increases the previously recognized circumpolar permafrost peat OC pool by $50 \%$. Here we show that these sediments were already accounted for by previous studies.

The calculations of overlap in soil carbon stocks between different estimates and data sets for the Siberian Yedoma region are based on data on soil and/or sediment carbon stocks from Tarnocai et al. (2009), Hugelius et al. (2013a, b, 2014) and Walter Anthony et al. (2014). By using the reported depth ranges and soil carbon densities of the different studies, the overlap between estimates has been calculated following the same methods used in the original studies. We refer to the online method section for more details on the calculations.

Previous integrated estimates of carbon stocks in the Beringian Yedoma region (Tarnocai et al., 2009; Hugelius et al., 2014) are based on soil maps linked to field-based soil data for the upper $3 \mathrm{~m}$ and generalized estimates of Yedoma region deposits for deeper deposits (Zimov et al., 2006; Strauss et al., 2013). The Holocene thermokarst deposits described by Walter Anthony et al. (2014) overlap these previous estimates in space, but they differ in their characterization of the sediment (Fig. 2). An important difference compared to previous studies is that Walter Anthony et al. (2014) include $24 \mathrm{Pg}$ carbon in Holocene deposits assumed to occur in taliks (perennially thawed ground) under present day lakes and rivers. We recognize that these estimates are new, but they are also outside the scope of the studies by Tarnocai et al. (2009) and Hugelius et al. (2014) as they are per definition not terrestrial soils, nor are they permafrost deposits. Out of the $159 \mathrm{Pg}$ of Holocene alas carbon reported by Walter Anthony et al. (2014), this leaves $135 \mathrm{Pg}$ of Holocene carbon to be reconciled with previous estimates for soil and/or sediment that occupy the same physical space. For the upper $3 \mathrm{~m}$, Walter Anthony et al. (2014) estimate 76 Pg of Holocene carbon. This overlaps soils from previous estimates with carbon stocks of 53-58 Pg in 0-3 m soils from the NCSCD (range based on different versions of the NCSCD from Tarnocai et al., 2009; Hugelius et al., 2013a, b, 2014). This comparison would result in a $\sim 20 \mathrm{Pg}$ net increase. Note that the OC stock estimates of Walter Anthony et al. (2014) are extrapolated from 28 sites with a geographical distribution limited to the Kolyma river lowlands (see Fig. 1). We do not consider this new estimate to be more robust than previous estimates based on the NCSCD.

For alas deposits below $3 \mathrm{~m}$, the estimate by Walter Anthony et al. (2014) includes $60 \mathrm{Pg}$ of Holocene OC and $155 \mathrm{Pg}$ of Pleistocene OC which overlaps with estimates of $\sim 110 \mathrm{Pg}$ of OC in refrozen thermokarst sediments (Strauss et al., 2013; updated in Hugelius et al., 2014). The differences between estimates are primarily due to two reasons. Firstly, the previous estimates (Strauss et al., 2013; Hugelius et al., 2014) did not include the pool of OC stored in subaqueous thawed sediments (estimated to $23 \mathrm{PgC}$ ) or taberites. Taberites are in situ thawed, diagenetically altered Yedoma deposits. Walter Anthony et al. (2014) estimate that these taberite deposits store $97 \mathrm{PgC}$. Second, the previous estimates applied medians from bootstrapping approaches to es- 
timate OC stocks in thermokarst sediment below $3 \mathrm{~m}$ depth while Walter Anthony et al. (2014) use arithmetic means. These different methods yield significant differences in estimated stocks. Walter Anthony et al. (2014) discuss how these estimates overlap. Further comparisons of these separate estimates and their methodological differences are outside the scope of the ideas and perspectives presented here.

\section{Conclusions and recommendations}

We conclude that Holocene OC stocks in Siberian Yedoma region alases which overlap estimates from previous studies are primarily stored in mineral soils and lacustrine sediments rather than peat and do not increase estimates of circumpolar permafrost peat carbon stocks. There is no evidence or reasoning to suggest that these deposits increase the northern peatland pool or that the NCSCD is systematically biased against upland soils. In fact, the differences between the estimates of Hugelius et al. (2014) and Walter Anthony et al. (2014) are rather small. If storage in taberites and subaqueous sediments is accounted for, the difference in estimated Yedoma region alas OC stocks is only $\sim 10 \mathrm{PgC}$, which is well within the reported uncertainty ranges.

We emphasize that our concerns regarding use of terminology and spatial overlap of estimates in the discussed study in no way affects the validity of their other important findings regarding Holocene carbon dynamics of these ecosystems. It is relevant and important to contrast the Holocene accumulation of carbon in alas sediments to that estimated for peatlands. We attribute the misunderstandings to confusing overlap between terminologies in the respective fields of science that study soils and sediments in periglacial landscapes. We suggest that a careful and exhaustive review of these terminologies would help future studies to harmonize classifications and definitions. The need for reconciliation of terminologies is emphasized by accumulating evidence that the differing properties of mineral and organic soil affect their vulnerability under future climatic changes.

\section{Data availability}

For more detailed descriptions of methods and the data sets used in this paper, please consult the supplementary materials. The GIS database and pedon data for the NCSCDv2 (Hugelius et al., 2013b) is avaiable via: http://bolin.su.se/data/ncscd/. The following indepedent geospatial datasets were used in this study: Global Land Cover Map for 2009 (GlobCover 2009; Arino et al., 2009; available via: doi:10.1594/PANGAEA.787668), Global Land Cover 2000 (GLC2000; Bartalev et al., 2003; available via: http: //forobs.jrc.ec.europa.eu/products/glc2000/products.php), Global Lakes and Wetlands Database (GLWD, Lehner and Döll, 2004; available via: http://www.worldwildlife. org/pages/global-lakes-and-wetlands-database) and Land Resources of Russia CD-ROM version 1.1 (Nilsson et al., 2002; Stolbovoi, 2002; available via: http://webarchive.iiasa. ac.at/Research/FOR/russia_cd/download.htm, 2002). The independent validation field site data are available from the authors upon request. These data are planned to be made openly available via the International Soil Carbon Network (http://iscn.fluxdata.org).

Acknowledgements. We are grateful to K. M. Walter Anthony, S. A. Zimov, G. Grosse, M. C. Jones, P. M. Anthony, F. S. Chapin III, J. C. Finlay, M. C. Mack, S. Davydov, P. Frenzel and S. Frolking for constructive scientific correspondence regarding the issues discussed in this manuscript, both prior to our submission to this journal and during the open discussion stage. We are grateful to three anonymous reviewers for very constructive comments which helped us write a better and more interesting manuscript. We acknowledge J. Palmtag, N. Weiss and M. Siewert for contributing to soil classification of the validation field sites. G. Hugelius acknowledges funding from the Swedish Research Council (grant number E0689701) and the EU JPI COUP project.

Edited by: R. Conant

\section{References}

Arino, O., Ramos Perez, J. J., Kalogirou, V., Bontemps, S., Defourny, P., and Van Bogaert, E.: Global Land Cover Map for 2009 (GlobCover 2009), European Space Agency (ESA) \& Université catholique de Louvain (UCL), doi:10.1594/PANGAEA.787668, 2012.

Bartalev, S., Erchov, D., Isaev, A., and Belward, A.: A new SPOT4Vegetation derived land cover map of Northern Eurasia, Int. J. Remote Sensing, 24, 1977-1982, 2003.

Charman, D.: Peatlands and Environmental Change, Chichester, John Wiley \& Sons Ltd, 2002.

Czudek, T. and Demek, J.: Thermokarst in Siberia and its influence on the development of lowland relief, Quaternary Res., 1, 103120, 1970.

Grosse, G., Robinson, J. E., Bryant, R., Taylor, M. D., Harper, W., DeMasi, A., Kyker-Snowman, E., Veremeeva, A., Schirrmeister, L., and Harden, J.: Distribution of late Pleistocene ice-rich syngenetic permafrost of the Yedoma Suite in east and central Siberia, Russia, US Geol. Surv. Open File Rep., 2013, 1-37, 2013.

Harden, J. W., Manies, K. L., Turetsky, M. R., and Neff, J. C.: Effects of wildfire and permafrost on soil organic matter and soil climate in interior Alaska, Glob. Change Biol., 12, 2391-2403, doi:10.1111/j.1365-2486.2006.01255.x, 2006.

Hopkins, D. M. and Kidd, J. G.: Thaw lake sediments and sedimentary environments, in: Proceedings, Fifth International Conference on Permafrost, 790-795, TAPIR Publishers, Trondheim, Norway, 1988.

Hugelius, G., Virtanen, T., Kaverin, D., Pastukhov, A., Rivkin, F.,Marchenko, S., Romanovsky, V., and Kuhry, P.: Highresolution mapping of ecosystem carbon storage and potential effects of permafrost thaw in periglacial terrain, Eu- 
ropean Russian Arctic, J. Geophys. Res., 116, G03024, doi:10.1029/2010jg001606, 2011.

Hugelius, G., Routh, J., Kuhry, P., and Crill, P.: Mapping the degree of decomposition and thaw remobilization potential of soil organic matter in discontinuous permafrost terrain, J. Geophys. Res.-Biogeo., 117, G02030, doi:10.1029/2011jg001873, 2012.

Hugelius, G., Tarnocai, C., Broll, G., Canadell, J. G., Kuhry, P., and Swanson, D. K.: The Northern Circumpolar Soil Carbon Database: spatially distributed datasets of soil coverage and soil carbon storage in the northern permafrost regions, Earth Syst. Sci. Data, 5, 3-13, doi:10.5194/essd-5-3-2013, 2013 a.

Hugelius, G., Bockheim, J. G., Camill, P., Elberling, B., Grosse, G., Harden, J. W., Johnson, K., Jorgenson, T., Koven, C. D., Kuhry, P., Michaelson, G., Mishra, U., Palmtag, J., Ping, C.-L., O'Donnell, J., Schirrmeister, L., Schuur, E. A. G., Sheng, Y., Smith, L. C., Strauss, J., and Yu, Z.: A new data set for estimating organic carbon storage to $3 \mathrm{~m}$ depth in soils of the northern circumpolar permafrost region, Earth Syst. Sci. Data, 5, 393-402, doi:10.5194/essd-5-393-2013, $2013 b$.

Hugelius, G., Strauss, J., Zubrzycki, S., Harden, J. W., Schuur, E. A. G., Ping, C.-L., Schirrmeister, L., Grosse, G., Michaelson, G. J., Koven, C. D., O’Donnell, J. A., Elberling, B., Mishra, U., Camill, P., Yu, Z., Palmtag, J., and Kuhry, P.: Estimated stocks of circumpolar permafrost carbon with quantified uncertainty ranges and identified data gaps, Biogeosciences, 11, 6573-6593, doi:10.5194/bg-11-6573-2014, 2014.

IUSS Working Group WRB: World reference base for soil resources 2006: First update 2007, Rep. 103, Food and Agric. Organ., U. N., Rome, 2007.

Jorgenson, M. T. and Osterkamp, T. E.: Response of boreal ecosystems to varying modes of permafrost degradation, Can. J. Forest Res., 35, 2100-2111, doi:10.1139/x05-153, 2005.

Jorgenson, M. T., Romanovsky, V., Harden, J., Shur, Y., ODonnell, J., Schuur, E. A. G., Kanevskiy, M., and Marchenko, S.: Resilience and vulnerability of permafrost to climate change, Can. J. Forest Res., 40, 1219-1236, doi:10.1139/X10-060, 2010.

Joosten, H. and Clarke, D.: Wise Use of Mires and Peatlands, Saarijärvi: International Mire Conservation Group and International Peat Society, 2002.

Kanevskiy, M., Jorgenson, T., Shur, Y., O’Donnell, J. A., Harden, J. W., Zhuang, Q., and Fortier, D.: Cryostratigraphy and Permafrost Evolution in the Lacustrine Lowlands of West-Central Alaska, Permafrost Periglac., 25, 14-34, doi:10.1002/ppp.1800, 2014.

Kivinen, E. and Pakarinen, P.: Geographical distribution of peat resources and major peatland complex types in the world. Annales Academiae Scientarium Fennicae, Series A III, GeologicaGeographica, no. 132, 1981.

Kuhry, P. and Turunen, J.: The postglacial development of boreal and subarctic peatlands, in: Boreal Peatland Ecosystems: Ecological Studies 188, edited by: Wieder, R. K. and Vitt, D. H., Berlin, Heidelberg: Springer-Verlag, 25-45, 2006.

Lappalainen, E.: Global Peat Resources, Finland: International Peat Society, 53-281, 1996.

Lehner, B. and Döll, P.: Development and validation of a global database of lakes, reservoirs and wetlands, J. Hydrol., 296, 1-4, $1-22,2004$

Morgenstern, A., Ulrich, M., Günther, F., Roessler, S., Fedorova, I. V., Rudaya, N. A., Wetterich, S., Boike, J., and Schirrmeister, L:
Evolution of thermokarst in East Siberian ice-rich permafrost: A case study, Geomorphology, 201, 363-379, 2013.

Murton, J. B.: Thermokarst-lake-basin sediments, Tuktoyaktuk Coastlands, western arctic Canada, Sedimentology, 43, 737-760, 1996.

National Wetlands Working Group: The Canadian Wetland Classification System, 2nd Edition, edited by: Warner, B. G. and Rubec, C. D. A., Wetlands Research Centre, University of Waterloo, Waterloo, ON, Canada, 68 pp., 1997.

Nilsson, S., Stolbovoi, V., and Shvidenko, A.: Land cover, Land Resources of Russia CD-ROM version 1.1, copyright IIASA and Russian Academy of Sciences, available at: http://webarchive. iiasa.ac.at/Research/FOR/russia_cd/download.htm, 2002.

Palmtag, J., Hugelius, G., Lashchinskiy, N., Tamstorf, M. P., Richter, A., Elberling, B. and Kuhry, P.: Storage, Landscape Distribution, and Burial History of Soil Organic Matter in Contrasting Areas of Continuous Permafrost, Arct. Antarct. Alpine Res., 47, 71-88, doi:10.1657/AAAR0014-027, 2015.

Routh, J., Hugelius, G., Kuhry, P., Filley, T., Kaislahti Tillman, P., Becher, M., and Crill, P.: Soil organic matter characteristics in permafrost terrain, European Russian Arctic: Lability, storage, and impact of thawing, Chem. Geol., 368, 104-117, doi:10.1016/j.chemgeo.2013.12.022, 2014.

Schädel, C., Schuur, E. A. G., Bracho, R., Elberling, B., Knoblauch, C., Lee, H., Luo, Y., Shaver, G. R., and Turetsky, M. R.: Circumpolar assessment of permafrost $\mathrm{C}$ quality and its vulnerability over time using long-term incubation data, Glob. Change Biol., 20, 641-652, doi:10.1111/gcb.12417, 2014.

Schirrmeister, L., Grosse, G., Wetterich, S., Overduin, P. P., Strauss, J., Schuur, E. A. G., and Hubberten, H.-W.: Fossil organic matter characteristics in permafrost deposits of the northeast Siberian Arctic, J. Geophys. Res., 116, G00M02, doi:10.1029/2011jg001647, 2011.

Schirrmeister, L., Froese, D., Tumskoy, V., Grosse, G., and Wetterich, S.: Yedoma: Late Pleistocene Ice-Rich Syngenetic Permafrost of Beringia, in: The Encyclopedia of Quaternary Science, edited by: Elias, S. A., vol. 3, 542-552, Amsterdam, Elsevier, 2013.

Schuur, E. A. G., Bockheim, J., Canadell, J. G., Euskirchen, E., Field, C. B., Goryachkin, S. V., Hagemann, S., Kuhry, P., Lafleur, P. M., and Lee, H.: Vulnerability of permafrost carbon to climate change: Implications for the global carbon cycle, BioScience, 58, 701-714, doi:10.1641/B580807, 2008.

Schuur, E. A. G., McGuire, A. D., Schädel, C., Grosse, G., Harden, J. W., Hayes, D. J., Hugelius, G., Koven, C. D., Kuhry, P., Lawrence, D. M., Natali, S. M., Olefeldt, D., Romanovsky, V. E., Schaefer, K., Turetsky, M. R., Treat, C. C., and Vonk, J. E.: Climate change and the permafrost carbon feedback, Nature, 520, 171-179, doi:10.1038/nature14338, 2015.

Shur, Y. L. and Jorgenson, M. T.: Patterns of permafrost formationand degradation in relation to climate and ecosystems, Permafrost Periglac., 18, 7-19, doi:10.1002/ppp.582, 2007.

Siewert, M. B., Hanisch, J., Weiss, N., Kuhry, P., Maximov, T. C., and Hugelius, G.: Comparing carbon storage of Siberian tundra and taiga permafrost ecosystems at very high spatial resolution, J. Geophys. Res.-Biogeo., 120, 1973-1994, doi:10.1002/2015JG002999, 2015.

Sjöberg, Y., Hugelius, G., and Kuhry, P.: Thermokarst Lake Morphometry and Erosion Features in Two Peat Plateau Areas of 
Northeast European Russia, Permafrost Periglac., 24, 75-81, doi:10.1002/ppp.1762, 2013.

Soil Classification Working Group: The Canadian System of Soil Classification, Agric. Agrifood Can. Publ., vol. 1646, 187 pp., NRC Res., Ottawa, Ont., Canada, 1998.

Soil Survey Staff: Keys to Soil Taxonomy, 11th edn., Nat. Resour. Conserv. Serv., U.S. Dep. of Agric., Washington, D. C., 2010

Stolbovoi, V.: Wetland ecosystems, Land Resources of Russia CDROM version 1.1, copyright IIASA and Russian Academy of Sciences, available at: http://webarchive.iiasa.ac.at/Research/FOR/ russia_cd/download.htm, 2002.

Strauss, J., Schirrmeister, L., Grosse, G., Wetterich, S., Ulrich, M., Herzschuh, U., and Hubberten, H.-W.: The deep permafrost carbon pool of the Yedoma region in Siberia and Alaska, Geophys. Res. Lett., 40, 6165-6170, 2013GL058088, doi:10.1002/2013GL058088, 2013.

Strauss, J., Schirrmeister, L., Mangelsdorf, K., Eichhorn, L., Wetterich, S., and Herzschuh, U.: Organic-matter quality of deep permafrost carbon - a study from Arctic Siberia, Biogeosciences, 12, 2227-2245, doi:10.5194/bg-12-2227-2015, 2015.

Tarnocai, C., Canadell, J. G., Schuur, E. A. G., Kuhry, P., Mazhitova, G., and Zimov, S.: Soil organic carbon pools in the northern circumpolar permafrost region, Global Biogeochem. Cy., 23, GB2023, doi:10.1029/2008GB003327, 2009.

Veremeeva, A. and Gubin, S.: Modern tundra landscapes of the Kolyma Lowland and their evolution in the Holocene, Permafrost Periglac., 20, 399-406, 2009.

Walter Anthony, K. M., Zimov, S. A., Grosse, G., Anthony, P. M., Chapin, F. S. I., Finlay, J. C., Mack, M. C., Davydov, S., Frenzel, P., and Frolking, S.: A shift of thermokarst lakes from carbon sources to sinks during the holocene epoch, Nature, 511, 452$456,2014$.
Walter Anthony, K. M., Zimov, S. A., Grosse, G., Anthony, P. M., Chapin, F. S. I., Finlay, J. C., Mack, M. C., Davydov, S., Frenzel, P., and Frolking, S.: Interactive comment on "Ideas and perspectives: why Holocene thermokarst sediments of the Yedoma region do not increase the northern peatland carbon pool" by G. Hugelius et al., Biogeosciences Discuss., 12, C8785-C8792, 2016.

West, J. J. and Plug, L. J.: Time-dependent morphology of thaw lakes and taliks in deep and shallow ground ice, J. Geophys. Res., 113, F01009, doi:10.1029/2006JF000696, 2008.

Weiss, N., Blok, D., Elberling, B., Hugelius, G., Jørgensen, C. J., Siewert, M. B., and Kuhry, P.: Thermokarst dynamics and soil organic matter characteristics controlling initial carbon release from permafrost soils in the Siberian Yedoma region, Sediment. Geol., doi:10.1016/j.sedgeo.2015.12.004, in press, 2015.

Wetterich, S., Schirrmeister, L., Andreev, A. A., Pudenz, M. Plessen, B., Meyer, H., and Kunitsky, V. V.: Eemian and Late Glacial/Holocene palaeoenvironmental records from permafrost sequences at the Dmitry Laptev Strait (NE Siberia, Russia), Palaeogeogr. Palaeocl., 279, 73-95, 2009.

Zimov, S. A., Davydov, S. P., Zimova, G. M., Davydova, A. I., Schuur, E. A. G., Dutta, K., and Chapin, F. S.: Permafrost carbon: Stock and decomposability of a globally significant carbon pool, Geophys. Res. Lett., 33, L20502, doi:10.1029/2006GL027484, 2006. 